\title{
The use of chemically modified PVC waste to remove ions from wastewater
}

\author{
Abid Ouerghui ${ }^{\left.1,{ }^{*}\right)}$, Faycel Ammari ${ }^{2)}$, Christian Girard ${ }^{3)}$ \\ DOI: dx.doi.org/10.14314/polimery.2020.11.7
}

\begin{abstract}
Purified (in acetone, at $50^{\circ} \mathrm{C}$ for $72 \mathrm{~h}$ ), post-consumer PVC waste was grafted with 1,4-benzodioxane-6-amine and 2-aminobenzimidazole to increase its ability to remove ions from wastewater (from the Beja region, Tunisia). The PVC waste was characterized by IR spectroscopy, differential thermal analysis (DTA) and elemental nitrogen analysis. The ability of modified PVC waste to remove ions [sulphates ions $\left(\mathrm{SO}_{4}{ }^{2-}\right)$, nitrates ions $\left(\mathrm{NO}_{3}{ }^{-}\right)$, chloride ions $(\mathrm{Cl})$, carbonates ions $\left(\mathrm{CO}_{3}^{-}\right)$, metal ions $\left(\mathrm{Mg}^{2+}\right.$, $\left.\left.\mathrm{Zn}^{2+}, \mathrm{Na}^{+}, \mathrm{K}^{+} . ..\right)\right]$from wastewater was assessed based on ion conductivity measurements. It was found that modified PVC waste shows a greater efficiency in the removal of ions from wastewater than unmodified waste.
\end{abstract}

Keywords: PVC waste, chemical modification, wastewater, ions, conductivity.

\section{Zastosowanie chemicznie modyfikowanych odpadów PVC do usuwania jonów ze ścieków}

Streszczenie: Oczyszczone ( $w$ acetonie, $w$ temp. $50^{\circ} \mathrm{C}$ przez $72 \mathrm{~h}$ ), poużytkowe odpady PVC szczepiono 1,4-benzodioksano-6-aminą i 2-aminobenzimidazolem w celu zwiększenia ich zdolności do usuwania jonów $\left(\mathrm{SO}_{4}^{2-}, \mathrm{NO}_{3}{ }^{-}, \mathrm{Cl}^{-}, \mathrm{CO}_{3}{ }^{-}, \mathrm{Mg}^{2+}, \mathrm{Zn}^{2+}, \mathrm{Na}^{+}, \mathrm{K}^{+} ..\right)$z wód ściekowych (z regionu Beja, Tunezja). Odpady PVC scharakteryzowano za pomocą spektroskopii IR, różnicowej analizy termicznej (DTA) i analizy elementarnej azotu. Zdolność odpadów PVC do usuwania jonów znajdujących się w wodach ściekowych oceniono na podstawie pomiarów przewodnictwa jonowego. Stwierdzono, że modyfikowane odpady PVC wykazują większą skuteczność usuwania jonów znajdujących się w ściekach niż odpady niemodyfikowane.

Słowa kluczowe: odpady PVC, chemiczna modyfikacja, ścieki, jony, przewodnictwo.

Poly(vinyl chloride) (PVC) is used in many fields; for example, windows, frames, flooring, pipes, window blinds, wallpaper, hoses, cables and wires, coatings, plastisols, packing, medical tubing and blood bags [1, 2]. It's today found everywhere in the environment, and the volume of PVC waste in the environment is very important as its degradation requires a very long time. In 2015, about 6300 million tons of plastic waste were generated, $9 \%$ was recycled, $12 \%$ incinerated and $79 \%$ accumulated in the natural environment. At this rate, approximately 12000 million tons of plastic waste will be disposed in the natural environment in 2050 [3]. Plastic currently poses problems for health and for the environment, these problems are due to its durability [4], for example, the decomposition of polyethylene in the environment takes about 1000 years [5]. Coupled with a large production, this leads to an accumulation in the natural environment estimated at 25 million tons per year [6]. To protect the environment from these pollutants, it's very important to recycle disposed PVC waste [7-9], and to valorize this recycled PVC after modification of its chemical structure [10]. In this work, we recycled PVC waste by modification of its chemical structure, and followed the application of the newly obtained material for the removal of mineral ions presents in wastewater. The idea of this work is summarized in Scheme A.

\footnotetext{
1) University of Jendouba, Higher Institute of Biotechnology of Beja, Unit of Functional Physiology and Valorization of Bioresources (UR17ES27), B.P. 382-9000 Beja, Tunisia.

2) University of Carthage, Faculty of Sciences of Bizerte, Laboratory of Organic Chemistry and Applications (Unit 05/UR/12-05 ), Bizerte, 7021 Tunisia.

3) Chimie Paristech-PSL Research University, National Chemical Engineering Institute in Paris, Unit of Chemical and Biological Technologies for Health, UMR 8258 CNRS/U 1022 Inserm, 11 rue Pierre et Marie Curie, Paris, 75005 France.

*) Author for correspondence: ouerghiabid@gmail.com
} 


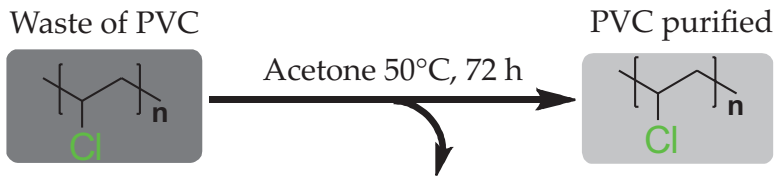

Elimination of additives

\section{Scheme A}

\section{EXPERIMENTAL PART}

\section{Materials}

1,4-Benzodioxan-6-amine $\left(\mathrm{C}_{8} \mathrm{H}_{9} \mathrm{NO}_{2}, M=151.16 \mathrm{~g} / \mathrm{mol}\right.$, $\geq 98 \%$ ), 2-aminobenzimidazole $\left(\mathrm{C}_{7} \mathrm{H}_{7} \mathrm{~N}_{3}, M=133.15 \mathrm{~g} / \mathrm{mol}\right.$, $97 \%)$, acetone $(\geq 99.5 \%)$, tetrahydrofuran $(\geq 99.9 \%)$, potassium iodide ( $\geq 99.9 \%), \mathrm{N}, \mathrm{N}$-dimethylformamide $(99.8 \%)$, ethanol $(99.8 \%)$, methanol $(99.8 \%)$, dichloromethane $(99.8 \%)$ and chloroform (99.9\%) were purchased from Sigma Aldrich.

\section{Purification of PVC waste}

The PVC waste was cut into small pieces with approximate dimensions $\left[\approx 3 \mathrm{~mm}^{3}: 1.7 \times 1.7 \times 1\right]$, then washed several times with distilled water and dried at room tem- perature. $5 \mathrm{~g}$ of PVC waste was mixed with $50 \mathrm{~cm}^{3}$ of acetone, and the mixture was heated at $50^{\circ} \mathrm{C}$ for 72 hours to remove impurities (organic pigments, metallic organo and alcohols). Then, the agglomerated PVC samples were ground and the purification process was repeated to remove the remaining impurities. A test of Bilstein was used for the detection of the presence of chlorine in the obtained material (polymer A), a green coloration of $\mathrm{Cl}$ was observed.The newly obtained polymer was characterized by IR spectroscopy.

\section{ATR/FTIR:}

$$
\text { A }-616(v \mathrm{C}-\mathrm{Cl}) \mathrm{cm}^{-1} \text {. }
$$

\section{Chemical modification of PVC waste}

$1 \mathrm{~g}$ of recycled PVC waste of polymer A obtained after elimination of additives was suspended in $50 \mathrm{~cm}^{3}$ of

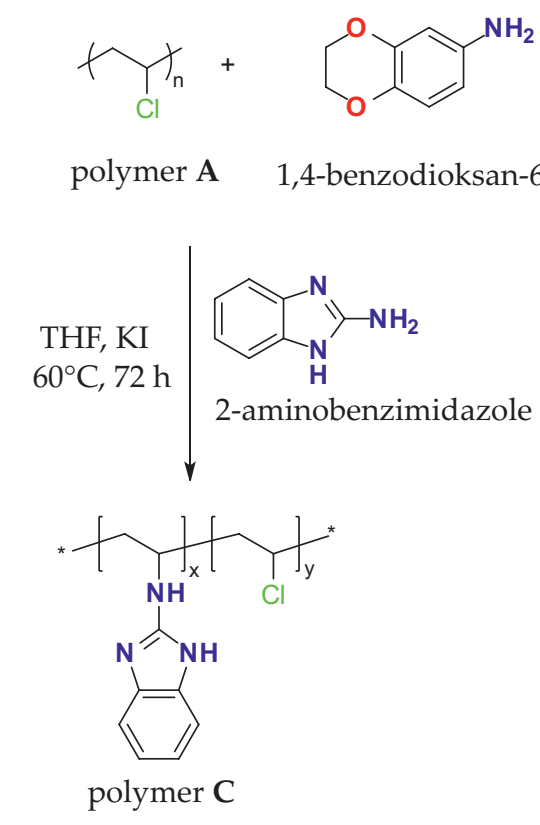

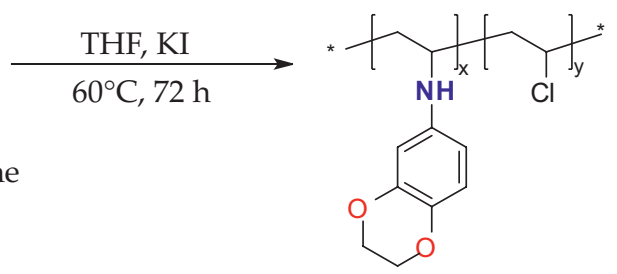

polymer B 
PVC waste

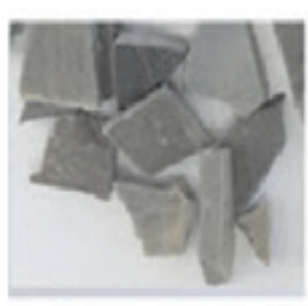

Polymer A

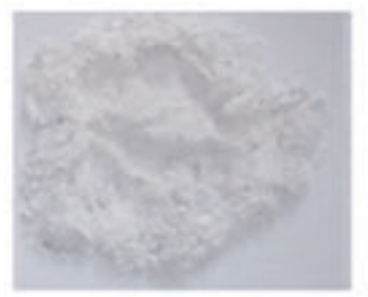

Polymer B

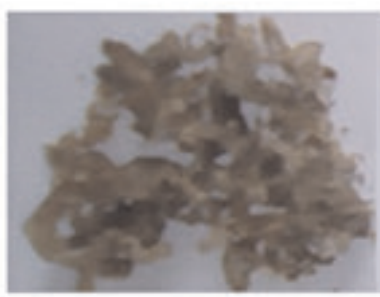

Polymer C

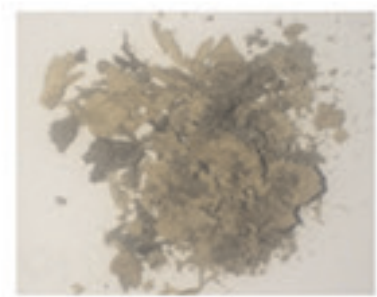

Fig. 1. Polymers obtained after chemical modification structure of PVC waste

THF for 15 minutes to facilitate the substitution reaction of chlorine by an amino group and $(0.048 \mathrm{~g}, 0.29 \mathrm{mmol})$ of $\mathrm{KI}$ and $16 \mathrm{mmol}$ of amino derivative were added. The reaction mixture was slowly magnetically stirred at $60^{\circ} \mathrm{C}$ for 72 hours (Scheme B).

The cooled mixture was filtered on sintered glass, washed with THF $\left(2 \times 20 \mathrm{~cm}^{3}\right)$, water $\left(3 \times 50 \mathrm{~cm}^{3}\right)$, and finally dried under a vacuum at $70^{\circ} \mathrm{C}$ for two days. The obtained polymers were insoluble in organic solvents $\left(\mathrm{CHCl}_{3}, \mathrm{CH}_{2} \mathrm{Cl}_{2}, \mathrm{MeOH}, \mathrm{EtOH}\right.$, acetone and DMF) but had a low solubility in THF. The substitution reaction of chlorine by an amine derivative was incomplete because the Belstein test revealed that the new polymers obtained after grafting amino groups still showed the existence of the green coloration with a low intensity.

The chemical modification of recycled PVC waste by amine derivatives used in this work was accompanied by a change of color in the polymers (Fig. 1), which confirms that the new obtained polymers are not equal to the control (polymer A), and the substitution reaction of chlorine by amine derivatives was realized.

\section{Extraction of minerals compounds from wastewater by ionic conductivity}

The polymers A, B, C were studied independently for the elimination of mineral compounds dissolved in wastewater [sulphates ions $\left(\mathrm{SO}_{4}{ }^{2-}\right)$, nitrates ions $\left(\mathrm{NO}_{3}{ }^{-}\right)$, chloride ions $\left(\mathrm{Cl}^{-}\right)$, carbonates ions $\left(\mathrm{CO}_{3}{ }^{2-}\right)$, metal ions $\left.\left(\mathrm{Mg}^{2+}, \mathrm{Zn}^{2+}, \mathrm{Na}^{+}, \mathrm{K}^{+} \ldots\right)\right]$. The samples of wastewater were taken from the treatment station of Beja region (36 $44^{\prime}$ North, $9^{\circ} 11^{\prime}$ East, Tunisia). The collection of samples of wastewater were taken in the first week of April 2019. The sampling of wastewater was taken by immersing a glass bottle in the basin to $20 \mathrm{~cm}$ depth. The sample was maintained at $4^{\circ} \mathrm{C}$ and filtered before treatment.

The polymer was incubated with wastewater at room temperature for 24 hours.

\section{Methods of testing}

- Infrared analysis using the Attenuated Total Reflectance Technique (ATR/FTIR) was made on a Nicolet FTIR 200 spectrophotometer (Thermo Scientific, France).
- Differential Thermal Analysis (DTA) was performed on a Setaram SETSY-1750 (France) in the temperature range between $25-45^{\circ} \mathrm{C}$ using reversible mode with a heating rate of $10^{\circ} \mathrm{C} / \mathrm{min}$, an oxidizing atmosphere was used by introducing analytical air and using alumina crucibles and calcinated alumina $\left(\mathrm{Al}_{2} \mathrm{O}_{3}\right)$ as reference.

- Elemental analysis of $\mathrm{N}$ was performed using a Perkin Elmer Analyzer CHN Series II 2400 (France).

- The $\mathrm{pH}$ of the solutions was measured using a Jenway ${ }^{\text {TM }} 3520 \mathrm{pH}$ meter.

- Test of Belstein: a copper wire is cleaned and heated in a Bunsen burner flame to form a copper(II) oxide coating. It is then immersed in the polymer sample to be tested and again heated with a flame. A positive test is indicated by a green flame caused by the formation of copper chloride.

- Extraction of mineral compounds located in waste water by ionic conductivity: the polymers $(\mathbf{A}, \mathbf{B}, \mathbf{C})$ were studied independently for the elimination of mineral compounds located in wastewater. $0.2 \mathrm{~g}$ of polymer was incubated with $20 \mathrm{~cm}^{3}$ of wastewater at room temperature for 24 hours, the incubation speed was $30 \mathrm{rpm}$. The amount of remaining ions in solution was evaluated by the ionic conductivity on a Jenway 4510 conductivity. The measurement of the ionic conductivity was carried out after calibration of the conductivity meter with standard solutions of $\mathrm{NaCl}$.

\section{RESULTS AND DISCUSSION}

\section{Chemical modification of PVC waste}

The results of the elemental analysis of nitrogen present in the obtained polymers A, B and C, were 0, 6.1 and $2.64 \%$, respectively. These percentages of nitrogen element were similar to those found by Mbarki et al. [10]. In Fig. 2, we present the IR spectra of commercial PVC, polymers A, B and C obtained before and after the chemical modification of PVC waste. The presence of the amino group (NH) in polymers $\mathbf{B}$ and $\mathbf{C}$ was confirmed by infrared spectroscopy on which its characteristic of valence vibration was seen near $3350 \mathrm{~cm}^{-1}$, the deformation band of $\mathrm{NH}$ was observed near $1600 \mathrm{~cm}^{-1}$, these bands were 

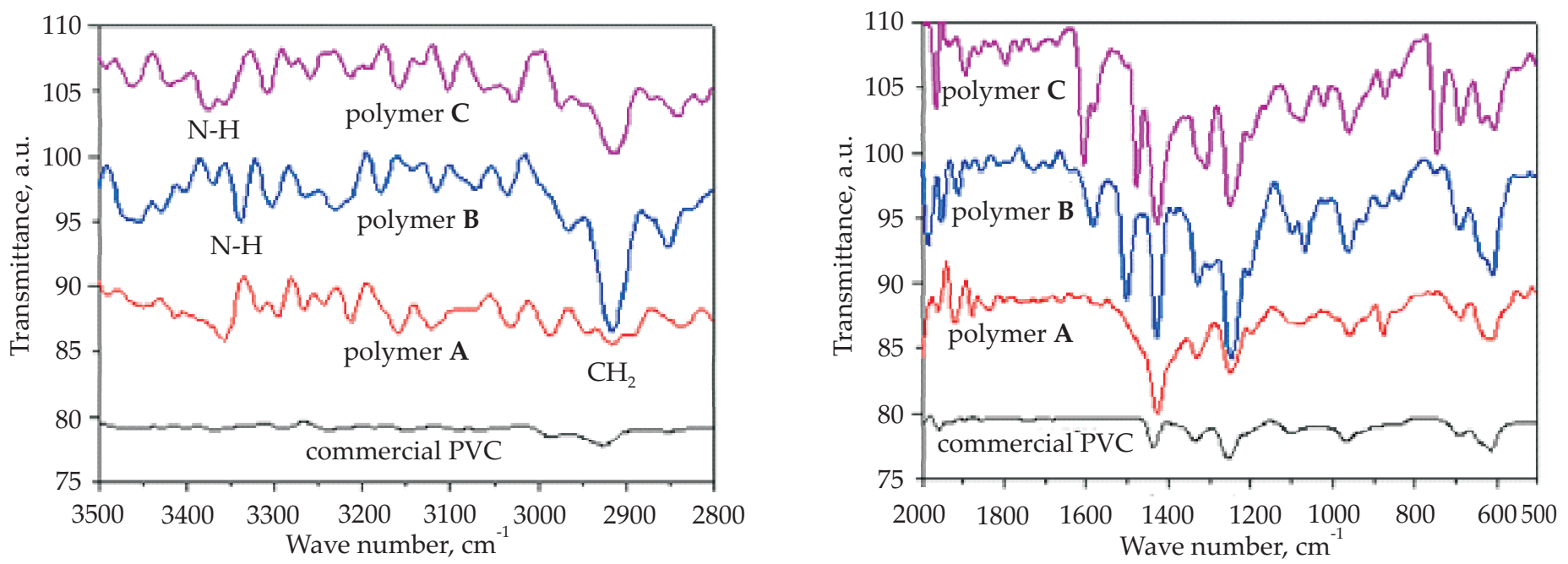

Fig. 2. IR spectrum of new polymers obtained after chemical modification structure of PVC waste

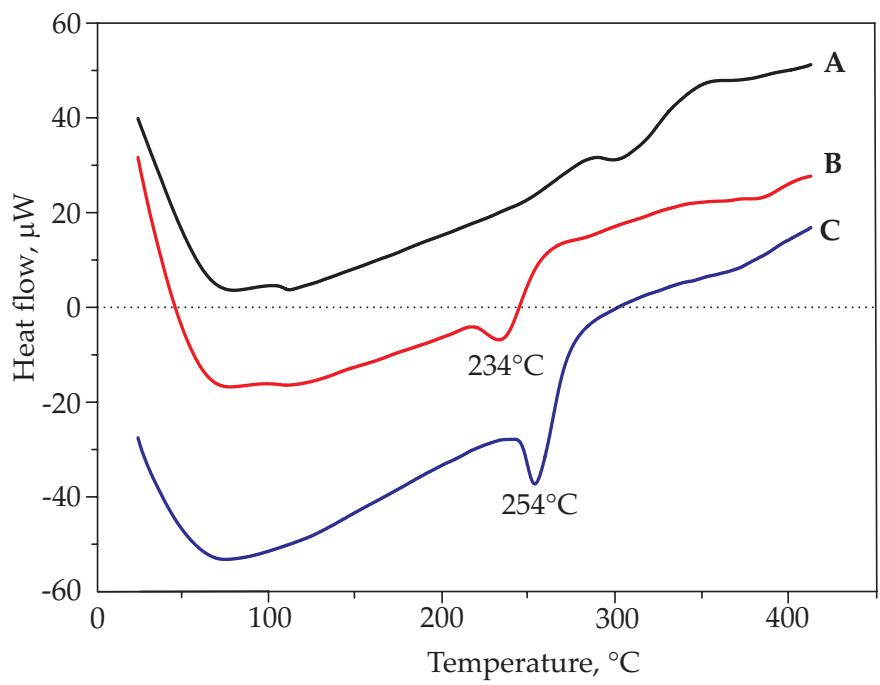

Fig. 3. Thermograms DTA of obtained after chemical modification structure of PVC waste

not observed in the commercial PVC and PVC waste (A) used as the control in this study, the valence vibration $\mathrm{C}=\mathrm{C}$ of aromatic bond was observed near $1500 \mathrm{~cm}^{-1}$ for polymers $\mathbf{B}$ and $\mathbf{C}$, the band observed at $1070 \mathrm{~cm}^{-1}$ was attributed to the vibrations of the C-O-C group of the amine grafted onto the polymer (A), an intense band observed at $745 \mathrm{~cm}^{-1}$ characterizes the deformation of the $\left(\mathrm{C}_{\mathrm{Ar}}-\mathrm{H}\right)$, these bands were absent in the IR spectrum of recycled PVC (A). In addition, $\mathrm{sp}^{3} \mathrm{C}-\mathrm{H}$ bending of commercial PVC, waste PVC and polymers $\mathbf{B}$ and $\mathbf{C}$ appeared in the range of $1436-1255 \mathrm{~cm}^{-1}$ as a set of two or more peaks, these results of IR spectroscopy were similar to those obtained by Das and Tiwari [10, 11].

The DTA curves of studied polymers A, B and $\mathbf{C}$ are shown in Fig. 3. The DTA thermograms of polymers $\mathbf{B}$ and $\mathrm{C}$ show an endothermic peak observed at 234 and $254^{\circ} \mathrm{C}$, respectively, this peak was absent on the DTA curve of polymer $\mathbf{A}$, These results show that the obtained polymers $\mathbf{A}, \mathbf{B}$ and $\mathbf{C}$ are not identical.

\section{Extraction of mineral compounds from waste water by ionic conductivity}

The extraction percentage of mineral ions is given by the following formula :

$$
\% \text { Extraction }=\frac{\mu_{0}-\mu_{\mathrm{f}}}{\mu_{0}} \cdot 100
$$

where: $\mu_{0}$ was the initial conductivity of the wastewater before treatment, $\mu_{\mathrm{f}}$ was the conductivity of waste water after treatment by studied polymers.

The results of ionic conductivity are presented in Fig. 4. Recycled PVC waste (polymer A) was used as a control in this present work, the conductivity of wastewater not treated by the studied polymers was in the order of $1300 \mu \mathrm{S} / \mathrm{cm}$. The conductivity of wastewater treated by the control polymer A was described by a decreasing linear curve according the equation (conductivity $\left.=-0.6737 t+1303.5 \mu \mathrm{S} / \mathrm{cm} ; R^{2}=0.958\right)$ in the time range 0-600 hours, after 600 hours the conductivity of wastewater treated by polymer $\mathbf{A}$ becomes practically constant (conductivity $=-0.0616 t+954.24 \mu \mathrm{S} / \mathrm{cm} ; R^{2}=0.7694$ ), these results explain that the control polymer $\mathbf{A}$ was saturated by mineral ions over 600 hours.

The percentage of extraction of mineral ions by control polymer A does not exceed 30\% (Fig. 5). If we look at the application of the newly obtained polymers $\mathbf{B}$ and $\mathrm{C}$ in the treatment of wastewater, we notice that the conductivity decreased compared to the control polymer A. The conductivity of wastewater treated by polymer B obtained after grafting 4-phenoxyaniline on polymer $\mathbf{A}$ decreases according the equation (conductivity $\left.=-0.9743 t+1255.9 \mu \mathrm{S} / \mathrm{cm} ; R^{2}=0.8708\right)$ in the time range $0-360$ hours. After 360 hours, the conductivity of wastewater treated by polymer $\mathbf{B}$ decreases slowly according the equation (conductivity $=0.2935 t+1027 \mu \mathrm{S} / \mathrm{cm} ; R^{2}=$ 0.8783). Extraction of the mineral ions by polymer $\mathbf{C}$ was slightly better than that obtained with polymer $\mathbf{B}$, in the range time $0-430$ hours, the conductivity decreases 

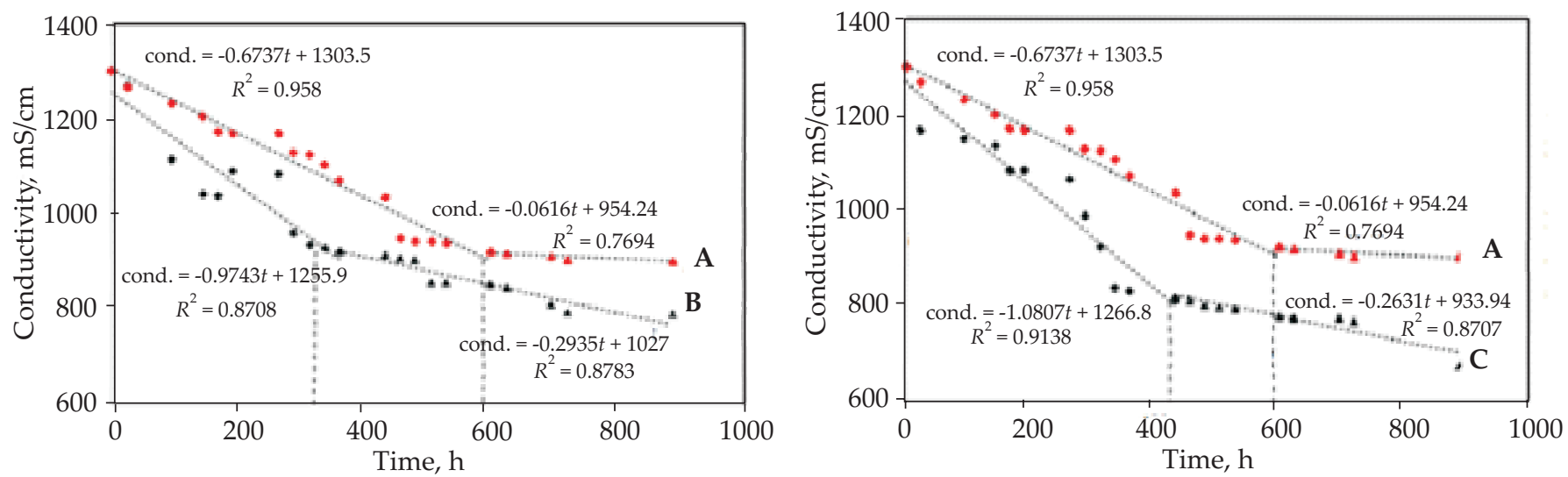

Fig. 4. Results of conductivity study of treatment of wastewater by new polymers obtained from PVC waste

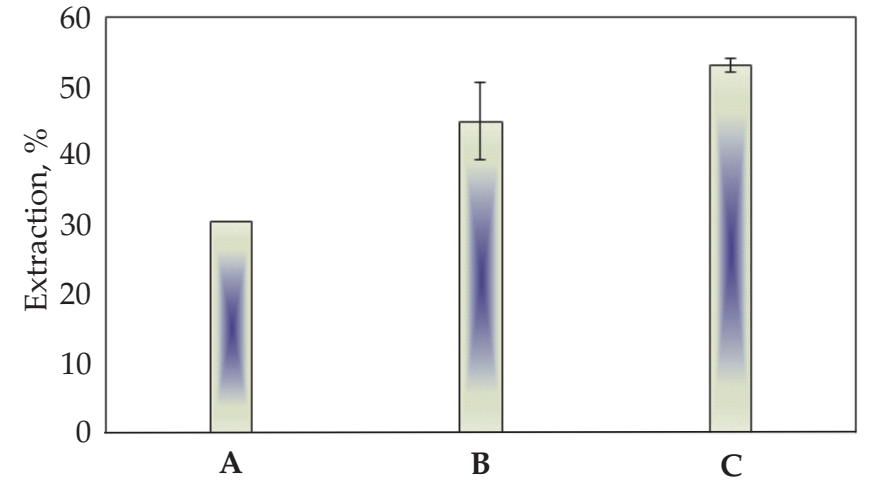

Fig. 5. Results of percentage extraction of mineral ions removed by polymers $A$, $B$ and $C$ from wastewater

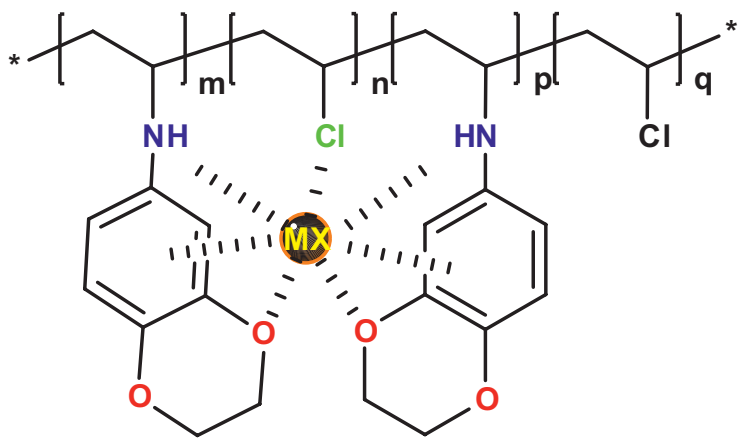

polymer B

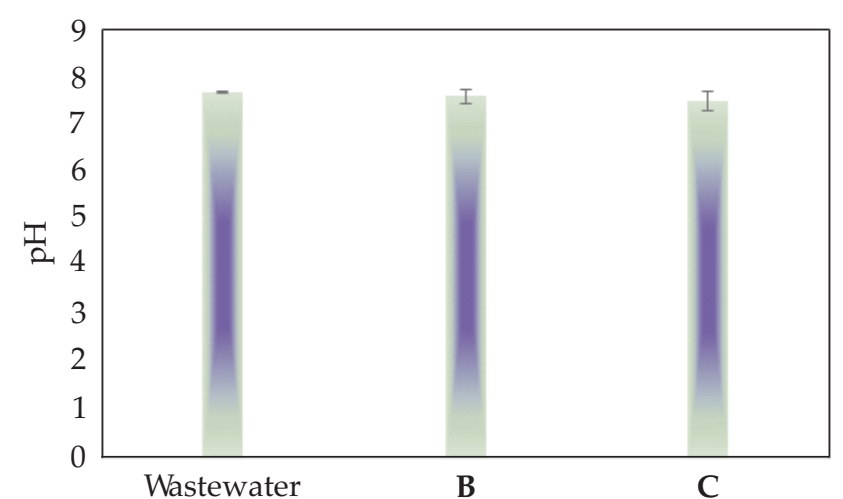

Fig. 6. $\mathrm{pH}$ of wastewater before and after treatment by polymers $B$ and $C$

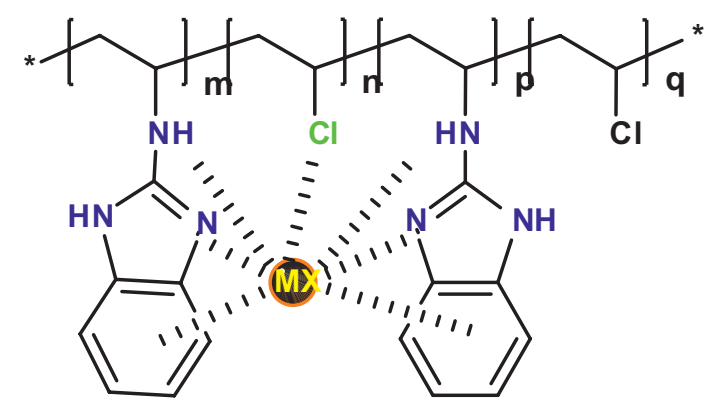

polymer $\mathbf{C}$

The percentage of extracted mineral ions by the control was in the order of $30.52 \pm 0.08 \%$, it's in the order of 44.91 $\pm 5.56 \%$ for polymer $\mathbf{B}$ and $52.96 \pm 1.03 \%$ for polymer C (Fig. 5). In this study, we didn't observe a high selectivity for the removal of mineral ions by polymers $\mathbf{B}$ and $\mathbf{C}$ by compared to the control polymer A. It is very important to change the operating conditions of the chemical modification structure of PVC waste by the grafting of amines to increase the percentage of nitrogen. The percentages water after 900 hours of extraction. 
of removal of mineral ions by polymers $\mathbf{B}$ and $\mathbf{C}$ are comparable to those found by Ammari and Meganem [12].

The $\mathrm{pH}$ of untreated and treated wastewater by polymers $\mathbf{B}$ and $\mathbf{C}$ are presented in Fig. 6. The $\mathrm{pH}$ of the untreated wastewater was about 7.8, after treatment by polymers $\mathbf{B}$ and $\mathbf{C}$, the $\mathrm{pH}$ decreased, the $\mathrm{pH}$ values for treated wastewater by polymers $\mathbf{B}$ and $\mathbf{C}$ were 7.6 and 7.5, respectively. This decrease in $\mathrm{pH}$ can be explained by the extraction of several basic chemical species: nitrates, sulphates, phosphates and amines [13-15].

Complexation with mineral ions may be best for polymer $\mathbf{C}$ rather than polymer $\mathbf{B}$ because of the combination of amino groups [10]. The mechanism of the retained mineral ions by new obtained polymers was presented in Scheme C.

\section{CONCLUSION}

In this study, PVC waste was purified by the removal of additive compounds and a chemical modification by grafting aromatic amines was realized. The new polymers obtained were characterized by IR spectroscopy, thermal analysis (DTA) and elemental analysis for nitrogen. The polymers obtained were tested for the elimination of mineral ions located in the wastewater of Beja region (Tunisia). The study of this elimination was followed by ionic conductivity. The polymers obtained after the chemical modification of PVC waste gave a better removal efficiency than the control, unmodified PVC waste. This percentage was in the order of $50 \%$ but this percentage is not remarkable as the degree of substitution of chlorine by nitrogen was very low. It is very important to optimize the protocol for the chemical modification of PVC waste.

\section{ACKNOWLEDGMENTS}

The authors would like to thank Mr. Faouzi Meganem (Professor Emeritus at the Faculty of Sciences in Bizerte, Tunisia).

\section{REFERENCES}

[1] Moulay S.: Progress in Polymer Science 2010, 35 (3), 303. http://dx.doi.org/10.1016/j.progpolymsci.2009.12.001

[2] Braun D.: Journal of Polymer Science, Part A: Polymer Chemistry 2004, 42 (3), 578.

http://dx.doi.org/10.1002/pola.10906

[3] Geyer R., Jenna R.J., Kara L.L.: Science Advances 2017, $3(7), 1$. http://dx.doi.org/10.1126/sciadv.1700782

[4] Shimao M.: Current Opinion in Biotechnology 2001, 12 (3), 242. http://dx.doi.org/10.1016/S0958-1669(00)00206-8

[5] Usha R., Sangeetha T., Palaniswamy M.: Libyan Agriculture Research Center Journal International 2004, 2 (4), 200.

[6] Kale S.K., Amit G.D., Dudhare M.S., Patil V.B.: Journal of Biochemical Technology 2015, 6 (2), 952.

[7] Tilmatinea A., Flazi S., Medles K. et al.: Journal of Electrostatics 2004, 61 (1), 21. http://dx.doi.org/10.1016/j.elstat.2003.11.004

[8] Achyut K.P., Singh R.K., Mishra D.K.: Renewable and Sustainable Energy Reviews 2010, 14, 233. http://dx.doi.org/10.1016/j.rser.2009.07.005

[9] Kiran N., Ekinci E., Snape C.E.: Resources, Conservation and Recycling 2000, 29, 273. http://dx.doi.org/10.1016/S0921-3449(00)00052-5

[10] Mbarki F., Ammari F., Ben Abdessalem K., Meganem F.: Journal of the Tunisian Chemical Society 2017, 19, 169.

[11] Das P., Tiwari P.: Conservation \& Recycling 2018, 128, 69. http://dx.doi.org/10.1016/j.resconrec.2017.09.025

[12] Ammari F., Meganem F.: Turkish Journal of Chemistry 2014, 38, 638. http://dx.doi.org/10.3906/kim-1306-24

[13] Houssine S., Andreas M., Uxua Perez de L. et al.: Carbohydrate Polymers 2016, 135 (1), 334. http://dx.doi.org/10.1016/j.carbpol.2015.08.091

[14] Özmen F., Kavaklı P.A., Güven O.: Journal of Applied Polymer Science 2011, 119 (1), 613. http://dx.doi.org/10.1002/app.32681

[15] Ouerghui A., Dardouri M., Sleimimi N. et al.: Polimery 2019, 64, 3. http://dx.doi.org/10.14314/polimery.2019.1.1 